\title{
Pelatihan Public Speaking Bagi Jemaat HKBP Karawang
}

\author{
Verdinand Robertua ${ }^{1}$, Indah Novitasari ${ }^{2}$, Angel Damayanti ${ }^{3}$, Singgih Sasongko ${ }^{4}$ \\ ${ }^{1}$ Prodi Hubungan Internasional, UKI, Jakarta, Indonesia \\ 2Prodi IImu Politik, UKI, Jakarta, Indonesia \\ ${ }^{3}$ Prodi Hubungan Internasional, UKI, Jakarta, Indonesia \\ ${ }^{4}$ Prodi IImu Komunikasi, UKI, Jakarta, Indonesia \\ E-mail: verdinand.robertua@uki.ac.id; indah.novitasari@uki.ac.id; \\ angel.damayanti@uki.ac.id; singgih.sasongko@uki.ac.id
}

\begin{abstract}
Abstrak
Kemampuan berbicara di depan publik bagi jemaat gereja menjadi sangat penting dalam menghadapi tantangan masyarakat digital saat ini. Fakultas IImu Sosial dan IImu Politik Universitas Kristen Indonesia melaksanakan pelatihan public speaking bagi jemaat HKBP Karawang pada hari Jumat, 23 April 2021. Metode pelatihan yang dilaksanakan menggunakan pemaparan materi mengenai strategi public speaking yang efektif dan simulasi public speaking oleh peserta. Setelah pelatihan dilaksanakan, survei kepuasan disebar dan dianalisis menggunakan SPSS. Hasil survei kepuasan menunjukkan kepuasan peserta dan rekomendasi keberlanjutan kegiatan.
\end{abstract}

Kata Kunci: pelatihan public speaking, HKBP Karawang, Fisipol UKI

\begin{abstract}
Public speaking skills for church community is very important in facing the new challenges in the digital age. Faculty of Social and Political Science Universitas Kristen Indonesia organized community service activity in the form of public speaking workshop to HKBP Karawang community member on Friday, 23 April 2021. The public speaking was conducted by the presentation and the simulation. After the training was completed, the participant filled the project satisfaction survey. The survey was analyzed using SPSS. The result showed that the participants were satisfied with the training and were recommended to be followed by subsequent training.
\end{abstract}

Keywords:public speaking training, HKBP Karawang, Fisipol UKI

\section{PENDAHULUAN}

Di tengah perkembangan teknologi komunikasi yang makin pesat dan menyentuh sendi-sendi kehidupan manusia, tantangan umat Kristen dalam menjaga relasi dan interaksi dengan sesamanya menjadi semakin berat. Sebagai bagian dari masyarakat, umat Kristen dituntut mampu melakukan komunikasi persuasif dengan saudara- saudara yang lain. Tentu hal ini tidak mudah karena kemajuan teknologi komunikasi menyebabkan orang lebih "suka" berkomunikasi menggunakan gadget/HP sebagai alat komunikasinya ketimbang berkomunikasi secara langsung (face to face communication). Semestinya, dengan teknologi komunikasi yang semakin canggih akan memudahkan siapapun untuk berkomunikasi. Faktanya 
tidak demikian. Apalagi komunikasinya dilakukan secara publik (public Speaking).

Guna menjawab tantangan dan fenomena tersebut, FISIPOL - UKI bekerjasama dengan Yayasan Visi Indonesia Unggul (VIU) mengadakan pelatihan Public Speaking Skills bagi warga gereja. Pada dasarnya, workshop/pembekalan ini merupakan kegiatan pengabdian kepada masyarakat yang ditujukan untuk pembinaan warga gereja Huria Kristen Batak Protestan (HKBP) KARAWANG dan hamba-hamba Tuhan dibawah koordinasi lembaga Visi Indonesia Unggul.

Kabupaten Karawang memiliki pertumbuhan jemaat Kristen yang sangat pesat. HKBP Karawang menjadi salah satu gereja terbesar di wilayah administrasi Karawang. Kebutuhan keahlian speaking menjadi sangat mendesak bagi para penatua dan guru sekolah minggu mengingat dinamika media komunikasi yang berubah. Dengan pertimbangan tersebut, HKBP Karawang menjadi salah satu gereja yang diajak menjadi peserta dari pembekalan ini.

Melalui pelatihan ini, umat Kristen diharapkan memiliki kesadaran akan pentingnya membangun komunikasi publik yang efektif dengan siapapun, terutama dikalangan kristiani ditengah derasnya terpaan media dan perangkat komunikasi yang semakin canggih. Umat Kristen juga diharapkan mampu tampil menjadi orator yang mumpuni sehingga proses diseminasi informasi menjadi lebih efektif dan tepat sasaran.

Pembekalan ini merupakan salah satu penerapan Tujuan Pembangunan Berkelanjutan/Sustainable Development Goals khususnya dalam sararan keempat yaitu pendidikan yang berkualitas. $\mathrm{Di}$ dalam sasaran keempat ini, perguruan tinggi dituntut untuk menjadi solusi bagi permasalahan di masyarakat melalui penerapan ilmu pengetahuan dan teknologi. Melalui pembekalan ini, Fisipol UKI berkontribusi dengan menghasilkan orator yang mumpuni khususnya dari kalangan kristiani.

Sejumlah pastor, suster, bruder, frater dan utusan dari kelompok Wanita Katolik Republik Indonesia (WKRI) mengikuti pelatihan public speaking di Pusat Karya Pastoral Keuskupan Denpasar, sejak Selasa, 16 Agustus hingga Jumat esok, 19 Agustus 2016 (Katoliknews.com 2016).

Partisipasi gereja diperlukan dalam dinamika politik di Indonesia. Seperti yang disampaikan oleh Rantung (2017), partisipasi gereja dalam politik pluralitas di Indonesia merupakan salah satu bagian penerapan koinonia yaitu persekutuan iman umat Kristen. Persekutuan iman 
umat Kristen menjadi sebuah contoh bagi penerapan politik kemajemukan di Indonesia. Gereja mendorong penerapan politik kemajemukan sesuai dengan Pancasila dan Undang-Undang Dasar 1945. Rantung (2017, 61) mengatakan bahwa "Gereja haruslah bersikap menjadi gereja yang membawa amanat Tuhan Yesus untuk kesejahteraan, kebenaran, keadilan, perdamaian dalam kehidupan masyarakat di Indonesia."

Saut Sirait (2016) menegaskan bahwa gereja memiliki tugas untuk membela masyarakat yang lemah dan tertindas. Yesus Kristus mengatakan bahwa umat Kristen harus menjadi terang dan garam bagi dunia. Bagi Saut Sirait, menjadi terang dan garam bagi dunia berarti keterlibatan aktif gereja dalam program sosial kemasyarakatan yang membawa kesejahteraan, keadilan dan perdamaian khususnya bagi Indonesia. FX Gian Tue Mali (2021) menjabarkan secara detail bagaimana kemiskinan dan ketertinggalan dihadapi oleh umat Kristen yang menjadi masyarakat mayoritas di Provinsi Papua, Provinsi Papua Barat, Provinsi Nusa Tenggara Timur, dan Provinsi Maluku.

Salah satu usulan yang dibahas Mali adalah pembentukan partai politik Kristen. Partai politik adalah mesin demokrasi yang menghasilkan pemimpin yang mengambil keputusan di berbagai level (nasional, provinsi dan lokal) dan berbagai bidang (ekonomi, politik, sosial, lingkungan dan budaya). Keberadaan partai politik Kristen diharapkan memberikan perubahan signifikan dalam tata kelola keuangan, daya saing ekonomi, kualitas pendidikan dan kesehatan serta perlindungan lingkungan hidup di wilayah-wilayah yang mengalami kemiskinan dan ketertinggalan khususnya di empat provinsi yang memiliki mayoritas umat Kristen.

Kemampuan berbicara di depan publik merupakan sebuah kemampuan yang perlu ditumbuhkembangkan. Berorasi menjadi sebuah tantangan bagi sebagian orang karena masalah psikologi dan kognitif. Masalah psikologi terkait dengan perasaan gugup dan kurang percaya diri sedang masalah kognitif terkait dengan materi yang diorasikan. Terdapat begitu banyak orator yang berasal dari Amerika Serikat dan Eropa Barat tetapi sangat sedikit orator yang berasal dari negara-negara berkembang.

Pemaknaan isi pidato di negara berkembang lebih fokus kepada kesejahteraan sedangkan isi pidato di negara maju lebih fokus kepada adaptasi perubahan. Konten yang disampaikan pada saat berbicara di depan publik menyesuaikan karakteristik budaya masing-masing masyarakat (Waheed, et 
al. 2011). Gereja perlu menyusun konten dan mempersiapkan pembicara yang menyesuaikan dengan kepentingan dan aspirasi gereja. Conceptual gap yang masih belum dibahas adalah pemaknaan pidato dan orasi publik dan kepentingan gereja dalam penambahan orator.

Penelitian ini termasuk dalam penelitian terapan (action research). David Tripp (2005) mendefinisikan penelitian terapan sebagai "a form of action inquiry that employs recognised research techniques to inform the action taken to improve practice." Menurut Burns (2015), terdapat empat karakteristik penelitian terapan yaitu (i) penelitian yang dilakukan membawa perubahan positif bagi partisipan, (ii) menghasilkan pengetahuan teoretis dan praktis terkait bidang ilmu yang dikaji, (iii) mengembangkan kolegialitas, keterlibatan dan partisipasi dari peserta dan (iv) memperkuat pengembangan diri dan perubahan konstan.

\section{METODE PELAKSANAAN}

Pelatihan diawali dengan masalah utama yang dihadapi masyarakat Indonesia yaitu kemampuan public speaking masyarakat Indonesia yang lebih rendah dibandingkan negara lain. Pelatih memberikan sebuah kutipan Jerry Seinfeld yang mengatakan bahwa: "Berdasarkan penelitian, ketakutan terbesar pertama bagi banyak orang adalah public speaking. Sedangkan ketakutan yang kedua adalah kematian. Ini artinya, bagi sebagian orang, lebih baik kita ada di dalam peti mati daripada harus memberikan pidato kematian dalam sebuah pemakaman."

Pelatih memperkuat motivasi peserta dengan pernyataan: "Nobody Born as Speaker". Melalui kutipan tersebut, peserta diajak untuk berani mengatasi masalah dan hambatan yang dihadapi untuk public speaking seperti mengabaikan potensi diri, kurangnya kepercayaan diri, tidak menguasai materi, dan tidak menguasai audience. Pelatih menjelaskan secara detail hambatanhambatan tersebut sehingga peserta dapat mengetahui faktor apa yang dihadapi ketika public speaking.

Pelatih masuk ke dalam sesi kedua dimana peserta akan berlatih membangun rasa percaya diri. Pelatih memberikan tipstips membangun kepercayaan diri yaitu memiliki citra diri yang positif, persepsi positif bahwa masyarakat membutuhkan peserta dan bukan menjatuhkan peserta, menguasai materi, melakukan latihan, mempersiapkan kalimat pembuka dan kalimat penutup dengan matang. Setelah memiliki persepsi positif terhadap diri sendiri, peserta dilatih menggunakan tips membuka public speaking seperti 
menggunakan kata-kata hypnotic, memulai dengan kisah seputar kehidupan manusia, melontarkan sebuah atau serangkaian pertanyaan, memulai dengan kutipan atau memulai dengan kisah lucu.

Setelah dilatih membuka public speaking, peserta dilatih untuk memiliki penampilan dan bahasa tubuh yang meyakinkan. Pelatih memberikan tiga tips dalam bentuk kutipan 3V yaitu visual, voice dan verbal. Verbal merupakan bagian public speaking yang menekankan pemilihan kata dan voice menekankan kepada intonasi, artikulasi, tempo, volume dan aksentuasi dari pembicara. Komponen utama dari $3 \mathrm{~V}$ adalah visual yang terdiri atas sentuhan, kontak mata, ekspresi wajah, pakaian dan penampilan serta gerakan tangan. Menurut penelitian yang dikutip pelatih, komponen verbal hanya mempengaruhi sebesar $7 \%$ dari kesuksesan public speaking dan voice menentukan sebesar 38\%. Komponen visual mempengaruhi paling besar dengan besaran 53\% dari kesuksesan public speaking.

Pelatih menyampaikan tiga hal yang harus diperhatikan dalam menggunakan bahasa tubuh yaitu bahasa tubuh harus cocok dengan apa yang diucapkan, bahasa tubuh harus wajar dengan tidak berlebihan atau terlalu sederhana dan terakhir, bahasa tubuh jangan terlalu sering diulang. Terkait ekspresi wajah, pelatih menekankan peserta untuk menciptakan ekspresi wajah yang berkesan kebahagiaan, menunjukkan keramahan dan tidak memperlihatkan kegugupan atau kegelisahan.

Terdapat beberapa hal yang harus dihindari oleh pembicara seperti penampilan yang loyo, tidak ada kontak mata dengan peserta, gerakan tubuh kurang terkontrol, tangan dimasukkan ke dalam saku celana/blazer dan menunjukkan kebosanan.

Setelah melatih voice, visual dan verbal, pelatih mengajak peserta ke dalam sesi terakhir yaitu mengatasi demam panggung. Menurut pelatih, sumber demam panggung berasal dari citra diri yang negatif, kurangnya penghargaan diri dan kurangnya menjaga penampilan. Setelah mengetahui sumber demam panggung, pelatih akan memberikan tipstips untuk mengatasi demam panggung.

Pelatih menutup pelatihan public speaking dengan memotivasi untuk terus berlatih dan tidak pernah menyerah apabila menghadapi persoalan terkait public speaking. 


\section{HASIL DAN PEMBAHASAN}

Pelatihan berbicara di publik merupakan implementasi tridharma Universitas Kristen Indonesia khususnya Fakultas IImu Sosial dan IImu Politik (Fisipol). Visi Fisipol UKI adalah menjadi fakultas ilmu sosial dan ilmu politik unggul di Asia Pasifik berdasarkan Pancasila dan nilai-nilai Kekristenan pada tahun 2027 (Fisipol UKI 2014). Fisipol UKI memiliki tiga program studi (prodi) yaitu IImu Politik, IImu Komunikasi dan Hubungan Internasional. Ketiga prodi ini memiliki kekhasannya tersendiri yaitu Prodi Hubungan Internasional yang fokus pada penerapan Tujuan Pembangunan Berkelanjutan di Asia Pasifik, Prodi Ilmu Komunikasi yang fokus pada jurnalisme multimedia dan hubungan masyarakat dan Prodi IImu Politik yang fokus pada otonomi daerah dan politik lokal.

\section{Pelatihan public speaking} dilaksanakan pada hari Jumat, 23 April 2021 di Ruang Aula UKI. Pelatihan ini menghadirkan pelatih Singgih Sasongko, anggota tim yang sudah berpengalaman melaksanakan pelatihan public speaking.

Kolaborasi ketiga prodi terlihat dalam pelaksanaan pelatihan berbicara di publik. Pelatih yang ditugaskan dalam pelatihan ini merupakan dosen prodi IImu Komunikasi yaitu Singgih Sasongko. Para peserta dilatih dasar-dasar teknik berkomunikasi yang efektif di publik.
Kompetensi tersebut sesuai dengan profil Iulusan dari Prodi IImu Komunikasi. Penentuan target peserta dan mitra kerjasama merupakan kontribusi dari Prodi IImu Politik dan Hubungan Internasional. HKBP Karawang dipilih sebagai target peserta melihat karakteristik masyarakat Karawang yang membutuhkan orator yang efektif dan efisien. HKBP Karawang memiliki 1420 anggota jemaat aktif dengan 32 penatua dan 21 guru sekolah minggu (Siahaan 2021). Berdasarkan kuesioner yang diisi oleh peserta, kebutuhan akan pelatihan ini terlihat jelas dan tegas. Masalah yang dihadapi oleh peserta adalah kegugupan dalam berbicara di publik. Penyampaian informasi yang penting bagi masyarakat dan Gereja menjadi terhambat karena kesulitan berbicara di publik. Dengan semakin banyaknya anggota Gereja di Karawang dan Bekasi, kompetensi berbicara di publik menjadi semakin penting.

Terdapat lima pertanyaan yang diajukan kepada peserta melalui Google forms yaitu apakah saudara sudah pernah mengikuti public speaking sebelumnya, hambatan apa saja yang dihadapi ketika berbicara di depan publik, apa harapan saudara dengan mengikuti pelatihan public speaking ini, dan apakah saudara 
bersedia mengikuti workshop public speaking ini sampai selesaia.

Dari hasil kuesioner, hampir semua peserta belum pernah mengikuti pelatihan public speaking. Salah satu hal yang menarik adalah latar belakang pendidikan peserta bervariasi mulai dari pendidikan terakhir sekolah menengah atas (SMA) hingga strata doktor (S3). Demikian pula dengan latar belakang usia yang bervariasi dengan usia paling muda 19 tahun dan paling tua 69 tahun. Pekerjaan para peserta bervariasi seperti mahasiswa, aparatur sipil negara, pengusaha atau pensiunan.

Dari pertanyaan terkait harapan keterlibatan dalam pelatihan public speaking ini, para peserta berharap dengan adanya pelatihan public speaking ini, para peserta dapat memahami urutan berbicara, mengendalikan audience, lebih berani dalam berbicara di depan publik, serta memperluas jaringan sosial. Banyak peserta yang berharap dapat menjadi pembicara yang handal setelah adanya pelatihan public speaking ini.

Untuk menguji kinerja dari panitia pelaksana pelatihan public speaking ini, peneliti menggunakan SPSS untuk menilai kepuasan para peserta. Tahap pertama yang dilakukan adalah mengukur keakuratan data customer satisfaction index (CSI). Perhitungan CSI di dapat dari nilai rataan tingkat kepentingan dan nilai rataan tingkat pelaksanaan kinerja dari masing-masing bobot.

Dari hasil Indeks Kepuasan Pelanggan $=$

(Total WS : skala maksimum) $\times 100 \%$ $=(4,55: 5) \mathrm{x}$

$=0,91 \times 100 \%$

$=91 \%$

Berdasarkan dari hasil tabel perhitungan yang telah dilakukan menggunakan CSI dapat diketahui bahwa indeks kepuasan konsumen terhadap layanan pendidikan di Program Studi IImu Politik sebesar $91 \%$ pada rentang skala 80 sampai dengan 100. Dapat dikatakan bahwa tingkat kepuasan konsumen secara umum berada pada kategori sangat puas.

Setelah melakukan CSI, peneliti melaksanakan importance performance analysis (IPA). Dalam metode IPA ini, kemudian dilakukan perhitungan selanjutnya yaitu perhitungan nilai tingkat kepentingan dan tingkat kinerja. Kemudian menghitung rata-rata tingkat kinerja $(X)$ dan rata-rata tingkat kepentingan $(\mathrm{Y})$ dan kemudian hasilnya akan dipetakan ke dalam diagram kartesius yang terbagi dalam 4 kuadran. 


\section{A. Rata-Rata Tingkat Kepentingan Dan Tingkat Kinerja}

Sebelum menentukan nilai kepentingan dan nilai kinerja konsumen ke dalam diagram kartesius terlebih dahulu mencari rata-rata dari tiap atribut dari nilai kepentingan dan nilai kinerja konsumen.

TABEL 1

HASIL PERHITUNGAN CUSTOMER SATISFACTION INDEX (CSI)

\begin{tabular}{|c|c|c|c|c|c|}
\hline No & \multicolumn{1}{|c|}{ Atribut } & $\begin{array}{c}\text { Rata-rata } \\
\text { Tingkat } \\
\text { Kepentingan }\end{array}$ & WF & $\begin{array}{c}\text { Rata- } \\
\text { rata } \\
\text { Tingkat } \\
\text { Kinerja }\end{array}$ & WS \\
\hline 1. & $\begin{array}{l}\text { Responden puas terhadap metode } \\
\text { atau cara penyampaian } \\
\text { narasumber dalam kegiatan } \\
\text { pengabdian yang telah } \\
\text { dilaksanakan }\end{array}$ & 4,58 & 0,66 & 4,54 & 0,14 \\
\hline 2. & $\begin{array}{l}\text { Materi yang disampaikan } \\
\text { meningkatkan kompetensi peserta }\end{array}$ & 4,46 & 0,63 & 4,50 & 0,14 \\
\hline 3. & $\begin{array}{l}\text { Responden puas terhadap } \\
\text { pelaksanaan kegiatan pengabdian } \\
\text { yang telah dilaksanakan oleh tim } \\
\text { PkM FISIPOL UKI }\end{array}$ & 4,46 & 0,63 & 4,50 & 0,14 \\
\hline 4. & $\begin{array}{l}\text { Pengabdian Kepada Masyarakat } \\
\text { ini dinilai bermanfaat bagi peserta }\end{array}$ & 4,50 & 0,64 & 4,46 & 0,14 \\
\hline 5. & $\begin{array}{l}\text { Kegiatan pengabdian yang telah } \\
\text { dilaksanakan dapat dilanjutkan } \\
\text { oleh Mitra Pengabdian }\end{array}$ & 4,50 & 0,68 & 4,65 & 0,15 \\
\hline Setiap & $\begin{array}{l}\text { keluhan/pertanyaan/permasalahan } \\
\text { yang saya ajukan ditindaklanjuti } \\
\text { dengan baik } \\
\text { narasumber/anggota yang terlibat }\end{array}$ & 4,54 & 0,65 & 4,50 & 0,14 \\
\hline 7. & $\begin{array}{l}\text { Peserta Bersedia terlibat apabila } \\
\text { kegiatan ini diselenggarakan } \\
\text { kembali }\end{array}$ & 4,58 & 0,66 & 4,46 & 0,14 \\
\hline
\end{tabular}


TABEL 2

NILAI RATA-RATA TIAP ATRIBUT

\begin{tabular}{|c|c|c|c|c|c|}
\hline No & Atribut & $\begin{array}{l}\text { Rata-rata } \\
\text { Tingkat } \\
\text { Kepentingan }\end{array}$ & $\begin{array}{l}\text { Rata- } \\
\text { rata } \\
\text { Tingkat } \\
\text { Kinerja }\end{array}$ & 4,52 & 4,52 \\
\hline 1. & \begin{tabular}{lrr}
\multicolumn{3}{l}{ Responden puas terhadap metode } \\
atau cara & penyampaian \\
narasumber & dalam & kegiatan \\
pengabdian & yang & telah \\
dilaksanakan & & \\
\end{tabular} & 4,58 & 4,54 & 4,52 & 4,52 \\
\hline 2. & $\begin{array}{l}\text { Materi yang disampaikan } \\
\text { meningkatkan kompetensi peserta }\end{array}$ & 4,46 & 4,50 & 4,52 & 4,52 \\
\hline 3. & $\begin{array}{l}\text { Responden puas terhadap } \\
\text { pelaksanaan kegiatan pengabdian } \\
\text { yang telah dilaksanakan oleh tim } \\
\text { PkM FISIPOL UKI }\end{array}$ & 4,46 & 4,50 & 4,52 & 4,52 \\
\hline 4. & $\begin{array}{l}\text { Pengabdian Kepada Masyarakat } \\
\text { ini dinilai bermanfaat bagi peserta }\end{array}$ & 4,50 & 4,46 & 4,52 & 4,52 \\
\hline 5. & $\begin{array}{l}\text { Kegiatan pengabdian yang telah } \\
\text { dilaksanakan dapat dilanjutkan } \\
\text { oleh Mitra Pengabdian }\end{array}$ & 4,50 & 4,65 & 4,52 & 4,52 \\
\hline 6. & $\begin{array}{l}\text { Setiap } \\
\text { keluhan/pertanyaan/permasalahan } \\
\text { yang saya ajukan ditindaklanjuti } \\
\text { dengan baik oleh } \\
\text { narasumber/anggota yang terlibat }\end{array}$ & 4,54 & 4,50 & 4,52 & 4,52 \\
\hline 7. & $\begin{array}{l}\text { Peserta Bersedia terlibat apabila } \\
\text { kegiatan ini diselenggarakan } \\
\text { kembali }\end{array}$ & 4,58 & 4,46 & 4,52 & 4,52 \\
\hline
\end{tabular}




\section{Kuadran I}

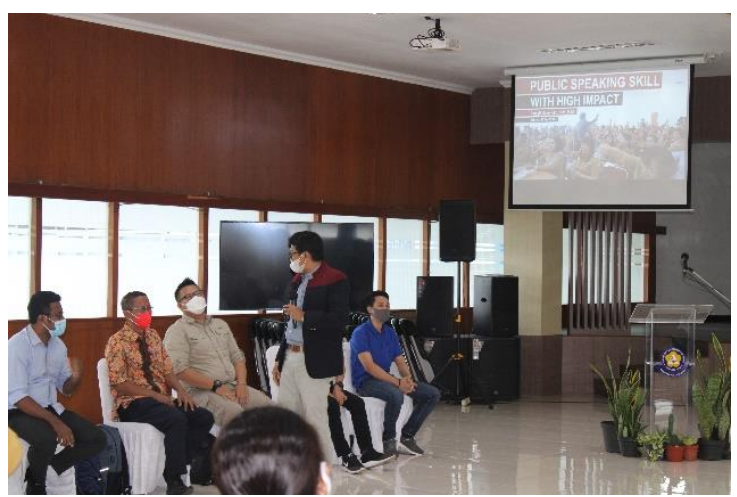

Gambar 1. Pelatih Mempresentasikan Strategi Public Speaking

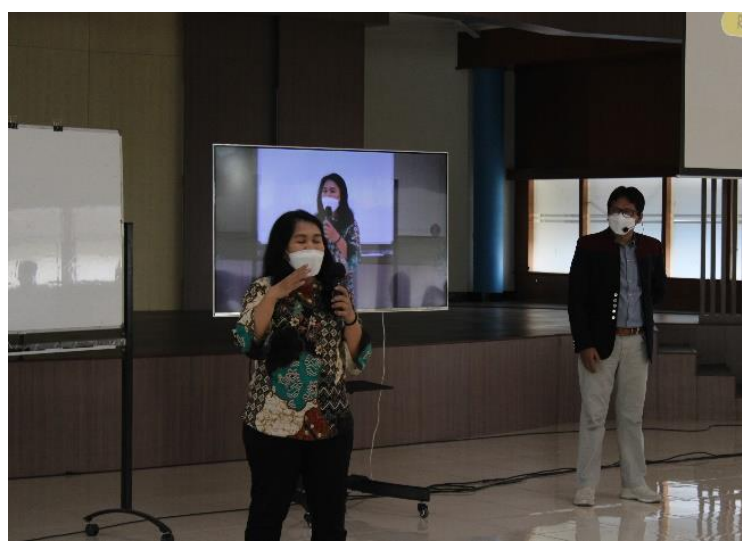

Gambar 2. Simulasi Public Speaking

\section{B. Diagram Kartesius}

Untuk menentukan perpotongan dari dua buah garis yang tegak lurus $(X)$ dan $(Y)$ sebagai pembagian daerah dengan rumus sebagai berikut :

$$
\begin{aligned}
& X=\underline{31,62}=4,52 \text { dan } Y= \\
& \underline{31,62}=4,52
\end{aligned}
$$

Kuadran I adalah Prioritas Utama dimana atribut-atribut yang di plotting ke dalam kuadran ini harus mendapatkan perhatian lebih atau harus diperbaiki. Hal tersebut menunjukkan bahwa konsumen merasakan ketidakpuasan terhadap atribut atau dimensi layanan yang telah diberikan, sehingga perlu adanya perbaikan pada atribut tersebut perlu diprioritaskan. Atributatribut tersebut antara lain

a. Setiap keluhan/ pertanyaan/ permasalahan yang saya ajukan ditindaklanjuti dengan baik oleh narasumber/anggota yang terlibat

b. Peserta Bersedia terlibat apabila kegiatan ini diselenggarakan kembali

Karena atribut tersebut dianggap sangat mempengaruhi kepuasan konsumen karena menunjukkan unsur jasa pokok namun dari pihak FISIPOL belum melaksanakannya sesuai harapan dari para konsumen, sehingga konsumen kecewa/kurang puas. Sebaiknya dari pihak FISIPOL secepatnya melakukan perbaikan pada atribut-atribut pada kuadran ini supaya konsumen bisa merasa puas 
dan mengurangi rasa kecewa dari FISIPOL.

\section{Kuadran II}

Kudran II adalah "Pertahankan Prestasi" dimana pada kuadran ini memiliki tingkat skor yang paling tinggi baik dari segi tingkat kepentingan konsumen dan tingkat kinerjanya, sehingga atribut yang berada pada kuadran II dapat dikatakan aman dan harus dipertahankan kinerjanya. Atribut yang di plotting ke dalam kuadran ini antara lain adalah

a. Responden puas terhadap metode atau cara penyampaian narasumber dalam kegiatan pengabdian yang telah dilaksanakan

\section{Kuadran III}

Kuadran III adalah "Prioritas Rendah", dimana atribut ini dianggap kurang penting pengaruhnya bagi konsumen dan pada kenyataan kinerjanya tidak terlalu istimewa. Bagi pihak FISIPOL sebaiknya perlu dipertimbangkan lagi pada atribut ini karena atribut yang masuk pada kuadran ini dianggap kurang penting dan kurang memuaskan bagi konsumen FISIPOL. Atribut yang di plotting ke dalam kuadran ini antara lain adalah

a. Materi yang disampaikan meningkatkan kompetensi peserta

b. Peserta puas terhadap pelayanan Tim/penyelenggara

c. Peserta merasakan manfaat dari pelaksanaan PKM ini.

\section{Kuadran IV}

Kuadran IV adalah "Berlebihan", ini menunjukkan bahwa atribut pada kuadran ini dinilai memiliki tingkat kepentingan yang rendah namun tingkat kinerja yang diberikan tinggi. Dianggap kurang penting tetapi pelayanan yang diberikan sangat memuaskan konsumen di FISIPOL. Atribut yang di plotting kuadran ini adalah

a. Kegiatan PKM ini dapat dilaksanakan kembali oleh Pelaksana (keberlanjutan)

\section{SIMPULAN}

Berdasarkan pada hasil penelitian yang telah dilakukan pada pelatihan public speaking yang dilaksanakan oleh Fisipol UKI kepada HKBP Karawang maka didapatkan kesimpulan sebagai berikut: 
a. Nilai tingkat kepuasan konsumen terhadap pelaksanaan Pengabdian Kepada Masyarakat adalah $91 \%$ artinya konsumen merasa "sangat puas" atas kinerja Pengabdian Kepada Masyarakat dari FISIPOL.

b. Untuk peningkatan kualitas pengabdian kepada masyarakat yang lebih optimal, pihak FISIPOL harus segera memperbaiki atribut-atribut antara lain

- Setiap keluhan/ pertanyaan/ permasalahan yang saya ajukan ditindaklanjuti dengan baik oleh narasumber/ anggota yang terlibat

- Penyampaian materi agar dapat meningkatkan kompetensi dan memberikan manfaat yang besar bagi peserta

- Peningkatan pelayanan tim/ pelaksana guna memenuhi kebutuhan peserta pada saat penyelenggaraan PKM

\section{SARAN}

Berdasarkan pada hasil pengolahan dan analisis yang telah dilakukan, maka dapat peneliti kemukakan beberapa saran yang diharapkan berguna bagi FISIPOL atau pihak-pihak yang bersangkutan dalam hal ini. Adapun saran-saran yang dapat disampaikan adalah sebagai berikut :

a. Pelaksanaan upaya perbaikan harus dipantau dan dievaluasi agar kepuasan konsumen benar-benar terpenuhi.

b. Tetap mempertahankan atributatribut yang dianggap sudah memuaskan konsumen sehingga pengabdian kepada masyarakat Fispol UKI akan lebih fokus untuk meningkatan pelayanan yang dianggap kurang.

\section{UCAPAN TERIMA KASIH}

Fisipol berterima kasih kepada HKBP Karawang dan LPPM UKI atas kerjasamanya dalam pelaksanaan PKM ini.

\section{REFERENSI}

Burns, Anne. 2015. "Action Research." In The Cambridge Guide to Research in Language Teaching and Learning, by J.D.

Brown and C. Coombe.

Cambridge University Press.

Fisipol UKI. 2014. Rencana Strategis

Fisipol UKI 2014-2019. Jakarta: UKI. 
Katoliknews.com. 2016. Pastor, Suster dan Awam Ikut Pelatihan 'Public Speaking'. Agustus 18. Accessed Mei 5, 2021. https://katoliknews.com/2016/08 118/pastor-suster-dan-awamikut-pelatihan-public-speaking/. Mali, FX Gian Tue. 2021. Debatable Kehadiran Partai Politik Kristen di Indonesia. April 28. Accessed April 28, 2021.

http://repository.uki.ac.id/2563/1 /DebatableKehadiranPartaiPoliti kKristendilndonesia.pdf.

Rantung, Djoys Anake. 2017. "Pendidikan Agama Kristen dan Politik dalam Kehidupan Masyarakat Majemuk di Indonesia." Shanan Jurnal Pendidikan Agama Kristen 5873.

Siahaan, Manat, interview by Verdinand Robertua. 2021. Profil HKBP Karawang (April 23).

Sirait, Saut. 2016. Teologi Kenegaraan: Negara dalam Rancangan Tuhan. Jakarta: BPK Gunung Mulia.

Tripp, David. 2005. "Action research: a methodological introduction." Educacao e pesquisa 443-466.
Waheed, Moniza, Andreas Schuck, Claes deVreese, and Peter Neijens. 2011. "More Different Than Similar: Values in Political Speeches of Leaders from Developed and Developing Countries." Journal of Intercultural Communication 77. 